\title{
EFL Teachers' Attitudes towards Being Supervised in an EFL Context
}

\author{
Ramin Rahmany \\ English Department, Islamic Azad University, Takestan Branch, Takestan, Iran \\ Mohammad Taghi Hasani \\ English Department, Islamic Azad University, Takestan Branch, Takestan, Iran \\ Kaivan Parhoodeh \\ Islamic Azad University Gillan-e-Gharb Center, Gillan-e-Gharb, Iran
}

\begin{abstract}
This study was an attempt to explore Iranian EFL teachers' attitude towards supervision and its influence on their classroom decision making. The study also examined the relationship between teachers' teaching experience and their attitude towards classroom supervision. 74 male and female English teachers holding BA, MA, or PhD degrees participated in this survey. Classroom observation and a teachers' questionnaire were used for the purpose of the study. The findings reveal that among the less experienced teachers those who had less than five years of teaching experience were found to be more influenced by the supervision process when it came to making decisions in the classroom. These teachers indicated the importance of supervision for their classroom improvement and their teaching skills and appeared to hold positive attitudes towards supervision program they were experiencing. Teachers with six to ten years of teaching experience appeared to be the most pessimists amongst others. In addition, from the results of the qualitative analysis it can be concluded that the supervision program obviously failed to function for those teachers who had 16 years of teaching experience and more as well. In this case, the program seemed to be only a paperwork job.
\end{abstract}

Index Terms - supervision, supervisor, attitude, EFL context

\section{INTRODUCTION}

Supervision is an indispensable process for organizational effectiveness. Being unsupervised causes organizations to be alone, disorganized, impenetrable and stabile (Kimbrough \& Burkett, 1990). As in all organizations, supervision is a very important process in educational organizations. The need for and importance of educational supervision have been emphasized by many authors (Pajak, 1993; Sergiovanni \& Starratt, 1993; Waite, 1995; Wiles \& Bondi, 1996; Sullivan \& Glanz, 2000; 2005; Oliva \& Pawlas, 2001; Glickman, Gordon \& Ross-Gordon, 2005; Aydın, 2005; Zepeda, 2006a; 2006b).

Supervision is commonly used in education as a tool to support understanding and development and it is one of the most challenging areas in program management. English language teaching (ELT) classroom observation has traditionally been seen as a part of teacher evaluation and supervisors are typically administrators and senior teachers. Feedback from supervisors as Sheal (1989) notes is usually unsystematic, subjective, and impressionist. Also, the relationship between observers and observees can be tense; the observers are evaluative, while the observees tend to be defensive. Classroom observations under such conditions might not help much in the observees' professional growth and development.

ELT classroom observations nowadays, however, have emphasized the need for holding more developmental than judgmental view in classroom observations. The main purpose of observations is not to judge subjectively what is good and bad teaching, but to work with the observee to explore and identify the limitations as well as the positive aspects in a class, thereby promoting the observee's critical thinking and professional growth. Such a view, as Williams (1989, p.85) states in an in-service teacher-training program, helps teachers to "develop their own judgments of what goes on in their own classrooms, sharpen their awareness of what their pupils are doing and the interactions that take place in their classes, and heighten their ability to evaluate their own teaching practices." This implies that observation can serve as an intermediary between teachers' teaching philosophies and practices. Nunan (1989, p. 76) also holds that since classrooms are "where the action is", spending time looking in classrooms can enrich our understanding of language learning and teaching.

\section{StATEMENT OF THE PRoblem}

Supervision in Iran's EFL context seems to be a one dimensional practice that needs improvements in both theoretical foundation and classroom practice. In some institutes and English Language Centers there is no observation 
system and the teachers (especially novice teachers) are faced with many problems in classes while they have passed TTC. In some other institutes where supervision is part of the policy of the institute, it is restricted to a paperwork job rather than a tool for teaching and hence learning improvement. Some other institutes have based their supervision practice on traditional theories of supervision in which the teacher has no role and his creativity and independence are mostly ignored.

Cooperation of knowledgeable and experienced supervisors with language teachers to have an effective teaching is a necessity. By systematic and focused observation of classrooms, the teachers and supervisors can gain insights into the nature of classrooms and into their teaching. They can use these insights to help them become more effective teachers.

For many years there has always been a question in the researcher's mind as to why some EFL institutes that have an experienced supervisor and a proper observation system for their teachers are more successful. One reason might be the role of suitable supervision on teachers' attitude and decision making in EFL Classes.

The purpose of this study is to discover Iranian EFL teachers' attitude towards supervision and its influence on their classroom decision making. The study also accounts for their differences and similarities in this respect and explores the relationship between teachers' teaching experience and their attitude towards classroom supervision.

\section{SIGNIFICANCE OF THE STUDY}

An appropriate observation system can help facilitate the achievement of the goals and expectations of an English teacher preparation program. Although a sufficient supervision is an important component of any teacher preparation program, little information is available about its effects on teachers' attitudes and decision making in EFL classes.

\section{RESEARCH QUESTIONS}

The present study will be an attempt to answer the following research questions:

1. Is teachers' attitude towards classroom supervision positive?

2. Is teachers' decision making in EFL classes influenced by classroom supervision?

3. Are attitudes of teachers towards classroom supervision significantly influenced by their teaching experience?

\section{MEthodology}

\section{A. Supervision and Its Purpose}

Supervision of instruction includes monitoring and analyzing classroom teaching practice and gathering appropriate data according to standards set by the administrator with the aim of providing meaningful feedback and direction to teachers to improve teaching and accordingly learning process. Through effective supervision of instruction, teaching practices can be strengthened and enhanced in order to contribute to improved student learning (Sergiovanni \& Starrat, 1983; Wiles \& Lovell, 1975; Harris, 1985).

It is clear that supervision is aimed to improve teaching instruction and to contribute to teacher's growth in order to enhance student learning. Because student learning is the primary goal of the schools, the effective supervision of instruction is an important tool in achieving that (reference). Administrators hold teachers accountable for providing an appropriate and well-planned program in which equal access to quality educational materials is provided for all students.

\section{B. Teachers and Instructional Supervision}

As explained in details, instructional supervision is meant to be "assistance for the improvement of instruction" (Glickman et al., 1998, p. 8), which is a "process that engages teachers in instructional dialogue for the purpose of improving teaching and learning and promoting student achievement" (Glanz, 2006, p. 55). However, not all teachers may view supervision as a positive force for program improvement or as source of assistance; some may consider it as a threat to the teacher's individuality (Wiles \& Lovell, 1975).

Research has shown that the improvement of the teaching-learning process through Instructional supervision is dependent upon teacher attitudes toward supervision (Fraser, 1980). In fact, instructional supervision will not promote teaching practice growth and enhance student learning unless the teachers perceive it that way.

In the following sections the notions of attitude and belief will be discussed and the related theories, models, and studies will be presented first. Then I will move on to integrating these concepts with the concept of instructional supervision in foreign language teaching context.

\section{Teachers' Attitudes and Beliefs towards Instructional Supervision}

Historically, teachers saw themselves as tools that could be closely examined to ensure that they carried out methods and procedures settled by the supervisors. Over the years this attitude has been noted and still exists among teachers, but some teachers now see the more positive aspects of supervision.

For example, in his study about the perceptions of Canadian and Ukrainian beginning high school teachers Kutsyuruba (2003) shows that the Canadian and Ukrainian participants indicated the importance of supervision for their professional growth and future career. The participants agreed that as beginning teachers they needed to grow and improve in order to become effective teachers. 
Cogan (1973) too says that some teachers now consider supervision as a necessary part of the administration of. They see the merit of the whole program if the supervisors are democratic and fair.

Gordon (1990) shows that although American teachers conveyed generally positive perceptions of the three supervisory approach of directive, non-directive, and collaborative, their response to non-directive supervision was less positive compared with the directive and collaborative approaches. He explains this by proposing the probability that these teacher might not be used to being given decision making responsibilities.

In Turkey, however, the situation was not the same. In an attempt to explore the supervisory process from the standpoint of Turkish supervised English language teachers Kayaoglu (2012) found that most of the EFL teachers were found to be pessimistic, depicting the current supervision as a negative experience and supervisors as bureaucratic administrators. Kayaoglu concluded that the current supervision that teachers of English receive does not lead to the growth of teachers and to the improvement of instruction. He proposed that some of the negative attitude towards the supervision results from the fact that most of the supervisors have no expertise in the field, and fail to diagnose problems specific to the field.

In Zimbabwe many teachers dislike or even fear being supervised because historically supervision has always been biased towards evaluation or inspection. Zimbabwean teachers seemed to have a negative view about supervision because supervisors were seen as inspectors who came on a fault-finding mission to the teachers' classroom. (Acheson \& Gall, 1997).

Human relations in supervision play an important role. Cogan (1973, p. 15) suggests that one of the main factors that affect supervision efficiency is the "unclarified, ambivalent relation of teachers to supervisors". Teachers prefer discussions with their supervisors about the observation. The relationship between teacher and supervisor is expected to be collegial rather than authoritarian. Wiles and Lovell (1975) suggest that teachers can perceive supervision as a useful activity if the supervisor gives teachers security by supporting their judgments and treat them fairly in the supervisory activities.

\section{Participants}

Seventy four EFL teachers participated in this study. The majority of the participants teach at Jahad Daneshgahi Language School in Kermanshah, Iran and the rest are from other English Language Institutes where teacher observation is regularly practiced. The participants are 43 males and 31 females. They are between 20 to 45 years old and their teaching experience range from one year to more than 20 years divided into five groups accordingly (1-5, 6-10, $11-15,16-20$, and +20 years). In addition, five participants from these five groups of experience were randomly chosen for classroom observation procedure.

The supervisors who observe and supervise the sample group regularly are also varied in their experience, gender, academic background and expertise. This diversity helps us in finding more accurate and inferable results.

\section{E. Materials}

A questionnaire was designed to collect data on how supervision affects Iranian EFL teachers' attitude and their decision making in EFL classes. The questionnaire was based on a tripartite approach to attitude which hypothesizes that there are three different components of emotional, cognitive, and behavioral that make up attitudes.

Accordingly, following the first part of the questionnaire that contains demographic questions in order to gain information about the teachers' and their supervisors' academic qualification, gender, age, and teaching experience, four sections will measure different aspects of Iranian EFL teachers' attitude toward classroom supervision based on the mentioned model of attitude using Likert-scale items. To be more precise, the second part measures how teachers evaluate the overall supervision program; the third part explores the teachers' beliefs and thoughts about mode of supervision and the teacher-supervisor relationship; the fourth part asks for teachers opinion about how the supervision program they are exposed to affects their professional growth; and finally in the fifth part teachers' reactions and behaviors towards supervision is explored.

To ensure the validity of the questionnaires and the appropriateness and comprehensibility of the questionnaire items, some experts in the field will be consulted. Moreover, the reliability coefficients (Cronbach's alpha) of instruments will be estimated and the results will be reported in the next chapter.

\section{F. Procedure}

For the quantitative part, a number of the questionnaires were distributed among teachers in Jahad Daneshgahi Language School in Kermanshah and the rest was submitted to teachers in other language institutes across the country via email. A few teachers answered the questionnaire after or between their class times, but most teachers assigned a time for returning the questionnaire, between 3 to 5 days. Participants were asked to take positions towards 21 statements. They were explained that these positions must most closely reflect their opinion about the current classroom supervision they are exposed to. Then the collected data was tabulated to be analyzed using SPSS (Statistical Package for Social Sciences) version 19.0 for Windows.

In addition, classroom observations were done to find how supervision influences teachers' decision making. 5 teachers from different teaching experience groups (1-5, 6-10, 11-15, 16-20, and +20 years) were chosen randomly for 
the purpose of the study. This enables us to compare supervision methods according to the experience of the teachers as well as different teachers' behavior towards supervision.

To explore the influence of the supervision on teachers' decision making observations took place in two phases: phase one at the session of classroom supervision, and phase two the session after the results of the observation has been reported to the teachers. Observations in the second session were done based on the feedback reports that were provided by the supervisor in the first session. That is, in the second session I check if the teacher has made changes in his teaching practice and decisions that he makes in the classroom based on the feedback report of the first session.

The results of classroom observations are also analyzed and reported based on the supervisors' feedbacks in the first session.

The reliability of the questionnaire was tested using Cronbach's alpha. Table 1 shows the result of the reliability test.

TABLE 1.

RELIABILITY STATISTICS OF THE QUESTIONNAIRE

\begin{tabular}{|l|l|}
\hline Cronbach's Alpha & N of Items \\
\hline .905 & 25 \\
\hline
\end{tabular}

The Cronbach's alpha of the questionnaire was 0.905 that indicates an excellent internal consistency of the questions, therefore a reliable measure.

\section{G. Teachers' Attitude towards Classroom Supervision}

Different aspects of teachers' attitude towards classroom observation were explored through the questionnaire. Bellow I will report the results of each part separately.

\section{H. General Evaluation of Supervision by EFL Teachers}

The initial part of the questionnaire explored the EFL teachers' general evaluation of classroom supervision according to their personal experiences. Table 2 summarizes their responses.

TABLE 2.

SUMMARY OF TEACHERS' GENERAL EVALUATION

\begin{tabular}{|ll|l|l|l|l|}
\hline & Frequency & Percent & Valid Percent & Cumulative Percent \\
\hline Valid & negative & 5 & 6.8 & 6.8 & 6.8 \\
& neutral & 44 & 59.5 & 59.5 & 66.2 \\
& positive & 25 & 33.8 & 33.8 & 100.0 \\
Total & 74 & 100.0 & 100.0 & \\
\hline
\end{tabular}

As Table 2 shows, among the 74 participants only 5 expressed negative judgments about classroom supervision. The table also shows that the majority of the teachers declared themselves to be neutral towards supervision and about 34 percent of the participants said that classroom supervision is good.

Table 3 shows the descriptive statistics of teachers' responses to the first question where they were asked about the usefulness of their supervision program.

TABLE 3.

DESCRIPTIVE STATISTICS OF TEACHERS' RESPONSES TO THE FIRST QUESTION

\begin{tabular}{|c|c|c|c|c|c|}
\hline & & Frequency & Percent & Valid Percent & Cumulative Percent \\
\hline \multirow[t]{4}{*}{ Valid } & disagree & 7 & 9.5 & 9.5 & 9.5 \\
\hline & no idea & 18 & 24.3 & 24.3 & 33.8 \\
\hline & agree & 49 & 66.2 & 66.2 & 100.0 \\
\hline & Total & 74 & 100.0 & 100.0 & \\
\hline
\end{tabular}

As Table 3 ahows the majority of the participants considered their classroom supervision program useful, about 24 percent were neutral toward it and only 9.5 percent found the in progress supervision program unproductive.

In the second question teachers were requested to evaluate the necessity of their classroom supervision. Table 4 reveals the summary of their evaluation.

TABLE 4.

DESCRIPTIVE StATISTICS OF TEACHERS’ RESPONSES TO THE SECOND QUESTION

\begin{tabular}{|ll|l|l|l|l|}
\hline & Frequency & Percent & Valid Percent & Cumulative Percent \\
\hline Valid & disagree & 15 & 20.3 & 20.3 & 20.3 \\
& no idea & 21 & 28.4 & 28.4 & 48.6 \\
agree & 38 & 51.4 & 51.4 & 100.0 \\
Total & 74 & 100.0 & 100.0 & \\
\hline
\end{tabular}

Table 4 shows that about half the participants found the supervision program necessary while the other half either disagreed or were on the fence. 
Finally, teachers were asked to rate the matter of paperwork formality of their classroom supervision and table 5 reveals the descriptive statistics of their evaluation.

TABLE 5.

DESCRIPTIVE STATISTICS OF TEACHERS’ RESPONSES TO THE THIRD QUESTION

\begin{tabular}{|ll|l|l|l|l|}
\hline & Frequency & Percent & Valid Percent & Cumulative Percent \\
\hline Valid & agree & 27 & 36.5 & 36.5 & 36.5 \\
& no idea & 32 & 43.2 & 43.2 & 79.7 \\
& disagree & 15 & 20.3 & 20.3 & 100.0 \\
& Total & 74 & 100.0 & 100.0 & \\
\hline
\end{tabular}

As the table suggests the teachers were not unanimous about the third question. While 36.5 percent considered their classroom supervision a matter of inevitable organizational and administrative paperwork duties, about 20 percent were in opposition to this view and the rest remained undecided.

\section{Teachers' Perceptions of the Mode of Supervision}

The next part of the questionnaire taps the EFL teachers' perceptions about the mode of supervision. In these questions the perceptions of teachers about the aims and objectives of the supervision, its influence on the teacher, and the supervisor-teacher relationship are explored. Table 6 provides us some clues to suggest possible trends and to give reasons why these teachers may develop certain attitudes towards supervision. Table 6 shows that the feeling of teachers towards supervision seems to be mixed. Their perception is mostly characterized by an apathetic feeling that is evident in the percentage of 'no idea' responses (an average 20 percent of the participants were undecided in answering the questions).

TABLE 6.

TEACHERS’ ATTITUDES TOWARDS MODE OF SUPERVISION

\begin{tabular}{|c|c|c|c|}
\hline \multirow[b]{2}{*}{ The current supervision } & \multicolumn{3}{|c|}{ Percentage } \\
\hline & Agree & No Idea & Disagree \\
\hline is more or less "looking for errors" & 39.2 & 23 & 37.8 \\
\hline is authoritative rather than democratic & 45.9 & 23 & 31.1 \\
\hline $\begin{array}{l}\text { includes sharing mutual responsibilities and participation between the } \\
\text { teacher and the supervisor }\end{array}$ & 38.1 & 4.1 & 57.8 \\
\hline is done with the aim of control, rather than improvement & 41.9 & 17.6 & 40.5 \\
\hline is inspection rather than a collaborative process & 44.6 & 23 & 32.4 \\
\hline creates fear and excitement in teachers & 66.2 & 17.6 & 16.2 \\
\hline focuses mostly on the teacher & 75.7 & 20.3 & 4 \\
\hline
\end{tabular}

Setting aside the undecided responses, comparing the views of the supporting and opposing participants gives us some clues that from teachers' point of view, the current supervisory practice is mostly characterized by inspection and evaluation. The percentage of teachers to whom the current supervision is authoritative and with the aim of inspection is higher $(45.9 \%$ and $44.6 \%$ ). For the majority of the teachers $(66.2 \%$ and $75.7 \%)$, supervision causes fear of being penalized, focuses mostly on the teacher, and does not invite participation on the part of the teacher, indicating that the supervisor- teacher relationship is a superior-inferior kind of relationship.

These interpretations are confirmed if we look at the overall evaluation of the participants in table 7.

TABLE 7.

SUMMARY OF TEACHERS' EVALUATION OF THE MODE OF SUPERVISION

\begin{tabular}{|ll|l|l|l|l|}
\hline & & Frequency & Percent & Valid Percent & Cumulative Percent \\
\hline Valid & negative & 29 & 39.2 & 39.2 & 39.2 \\
& neutral & 42 & 56.8 & 56.8 & 95.9 \\
& positive & 3 & 4.1 & 4.1 & 100.0 \\
Total & 74 & 100.0 & 100.0 & \\
\hline
\end{tabular}

As the table shows the majority of the teachers (56.8\%) were neutral towards the questions. A surprisingly low percentage $(4.1 \%)$ evaluated the mode of the current supervision they were exposed to positively and 39.2 percent were unsatisfied

\section{J. Teachers' Views about Contributions of Supervision to Their Growth}

Another aspect of teachers' attitude toward supervision that was tapped by the questionnaire was their views about how supervision helps with their professional improvement. Table 8 deals with their responses to this part. 
TABLE 8.

TEACHERS' VIEWS ABOUT CONTRIBUTIONS OF SUPERVISION TO THEIR GROWTH

\begin{tabular}{|c|c|c|c|}
\hline \multirow[b]{2}{*}{ The current supervision } & \multicolumn{3}{|c|}{ Percentage } \\
\hline & Agree & No Idea & Disagree \\
\hline guides us in problem-solving & 47.3 & 24.3 & 28.4 \\
\hline provides educational materials and assists in our courses & 28.4 & 39.2 & 32.4 \\
\hline increases our motivation and morale & 31.1 & 29.7 & 39.2 \\
\hline made contribution to my professional growth & 23 & 51.4 & 25.7 \\
\hline increased my teaching skills and practice & 37.8 & 29.7 & 32.4 \\
\hline helped me to discover my shortcomings & 54.9 & 8.1 & 37 \\
\hline helped me to overcome instructional problems & 47.3 & 27 & 25.7 \\
\hline
\end{tabular}

Surprisingly, the percentages of unconcerned responses in table 7 are again relatively high that seems to suggest that either the participants are indifferent towards supervision, or the supervision programs are mostly a matter of paperwork formality in the institutes that the study was implemented.

Once again due to high percentages of neutral responses, I have to put these responses aside and compare the affirmative and negative responses only. Accordingly, from the majority of teachers' point of view class supervision helps discover the teacher's shortcomings (54.9\%). In fact, more teachers find classroom supervision useful in guiding them to solve issues and help them overcome instructional problems (47.3\%). Though more teachers (37.8\%) agree that the current supervision they are exposed to enhances their teaching skills and practice, fewer of them consider the supervision a plus in their professional growth (23\%). They (32.4\%) think that the classroom supervision does not help them in their courses by providing educational materials. In addition, the supervision does not seem to be a stimulating and motivating factor to more teachers $(39.2 \%)$.

Table 9 summarizes the participants' evaluation of the contribution of supervision to their professional growth.

TABLE 9.

SUMMARY OF TEACHERS' EVALUATION OF THE CONTRIBUTION OF SUPER VISION TO THEIR PROFESSIONAL GROWTH

\begin{tabular}{|ll|l|l|l|l|}
\hline & Frequency & Percent & Valid Percent & Cumulative Percent \\
\hline Valid & negative & 18 & 24.3 & 24.3 & 24.3 \\
& neutral & 25 & 33.8 & 33.8 & 58.1 \\
& positive & 31 & 41.9 & 41.9 & 100.0 \\
Total & 74 & 100.0 & 100.0 & \\
\hline
\end{tabular}

All in all, table 9 shows that though 33.8 percent of the teachers were indifferent towards what classroom supervision may or may not add to them, 41.9 percent evaluated the contribution of supervision to their professional growth positively and a lower percentage of 24.3 hold opposing positions.

\section{K. Teachers' Manners and Reactions towards Supervision}

The last aspect of teachers' attitude is how they react towards supervision. This part attempts to explore the actual behavior of the teachers toward the supervision program they experienced. Table 10 shows the results.

TABLE 10.

TEACHERS' VIEWS ABOUT CONTRIBUTIONS OF SUPERVISION TO THEIR GROWTH

\begin{tabular}{llll}
\hline & \multicolumn{3}{l}{ Percentage } \\
\cline { 2 - 4 } After supervision I & Agree & No Idea & Disagree \\
\cline { 2 - 4 } study the evaluation report carefully & 68.9 & 6.8 & 24.3 \\
try to use the feedback to improve my teaching practice & 55.4 & 6.8 & 37.8 \\
try to change my teaching method according to the feedback & 45.9 & 2.7 & 51.4 \\
\hline
\end{tabular}

Table 10 shows an average positive behavior towards the supervision program results as the majority of teachers expressed that they read the report carefully $(68.9 \%)$ and make an attempt to utilize the feedback in improving their teaching practice $(55.4 \%)$. However, what is evident is that more teachers seem reluctant to change their teaching approach according to the feedback.

\section{Teachers' Decision Making and Classroom Supervision}

Classroom observations were done to find how supervision influences teachers' decision making (second research question). Five teachers with different teaching experiences were randomly chosen. This makes it possible to compare different teachers' behaviors and reactions towards supervision. Table 11 shows the participants information. 
TABLE 11.

OBSERVATION PART PARTICIPANTS' TEACHING EXPERIENCE

\begin{tabular}{|l|l|}
\hline \multicolumn{2}{|c|}{ OBSERVATION PART PARTICIPANTS ' TEACHING EXPERIENCE } \\
\hline Participant 1 & Teaching Experience \\
Participant 2 & 15 months \\
Participant 3 & 8 years \\
Participant 4 & 11 years \\
Participant 5 & 16 years \\
\hline
\end{tabular}

As was explained in chapter 3 in order to explore the influence of the supervision on teachers' decision making observations took place in two phases. In the first phase the actual supervision takes place and the evaluation forms are filled by the supervisor. Table 12 summarizes the negative points that the supervisors have made for each class separately. It is noteworthy to mention that the supervisors have mentioned the strength points of the teachers and their teaching practices however, I skip that part and focus on the criticisms and weak points for the purpose of the study.

TABLE 12.

SUPERVISORS' NEGATIVE POINTS

\begin{tabular}{|c|c|}
\hline $\begin{array}{l}\text { Participant } 1 \text { / Class } 1 \\
15 \text { months of teaching experience }\end{array}$ & $\begin{array}{l}\text { - Teaching procedures, aids and evaluation techniques are sometimes } \\
\text { inconsistent with the objectives: the objective of the teaching session } \\
\text { was to teach past tense and instead of linking the new material to the } \\
\text { previously known material the teacher used Persian language to teach } \\
\text { grammar. } \\
\text { - The teaching of grammar lacked warm-ups. } \\
\text { - The class lacked group work. } \\
\text { - Teacher correction was the dominant form of error correction. }\end{array}$ \\
\hline $\begin{array}{l}\text { Participant } 2 / \text { Class } 2 \\
8 \text { years of teaching experience }\end{array}$ & $\begin{array}{l}\text { - Teacher did not link the new lesson to students' personal experiences. } \\
\text { - Reading was only practiced by the teacher (the students were not } \\
\text { asked to repeat after the audio track). } \\
\text { - The class lacked the game part. }\end{array}$ \\
\hline $\begin{array}{l}\text { Participant } 3 \text { / Class } 3 \\
11 \text { years of teaching experience }\end{array}$ & - No comment \\
\hline $\begin{array}{l}\text { Participant } 4 \text { / Class } 4 \\
16 \text { years of teaching experience }\end{array}$ & - No comment \\
\hline $\begin{array}{l}\text { Participant } 5 \text { / Class } 5 \\
25 \text { years of teaching experience }\end{array}$ & - No comment \\
\hline
\end{tabular}

The results of the qualitative analysis in the first session of observation suggest that in the first two classes that the experience of teachers was less than 10 years supervision was based on the instructional steps of a predefined teaching method that these teachers have been taught in TCC (Teacher Training Course) at the time of starting their job at the language institute. Therefore, it seemed to be an inspection and control mechanism rather than a collaborative process.

However, this was not the case for the more experienced teachers. The experienced teachers and the supervisors seem to consider the supervision a paperwork job rather than an evaluation of the class for the purpose of improving teaching and learning and did not seem to care much about it.

The supervisor-teacher relationship in the classes that the teachers have more than 10 years of teaching experience was completely different. While the supervisor was strict with less experienced teachers and their relationship was more of a hierarchal relationship, the supervision process did not seem to be an important matter with more experienced teachers.

After the teachers had been provided with the feedbacks from the supervision session, the second phase of observation was conducted based on the points summarized in table 12. In the second phase I observed the classes comparing their present practices with what they were asked to do in the feedback report. The results are pointed out in table 13.

TABLE 13.

RESULTS OF THE COMPARISON OF THE TWO OBSERVATION SESSIONS

\begin{tabular}{|l|l|}
\hline \multicolumn{2}{|c|}{ RESULTS OF THE COMPARISON OF THE TWO OBSERVATION SESSIONS } \\
$\begin{array}{l}\text { Participant } 1 / \text { Class } 1 \\
\text { months of teaching experience }\end{array}$ & $\begin{array}{l}\text { - The teacher did not use Persian language and appropriate warm-up activities } \\
\text { were performed by the teacher. } \\
\text { - Group work practices were performed. } \\
\text { - Peer correction was practiced by the teacher as well as the teacher correction. }\end{array}$ \\
\hline $\begin{array}{l}\text { Participant } 2 / \text { Class } 2 \\
8 \text { years of teaching experience }\end{array}$ & $\begin{array}{l}\text { - The lesson was not personalized again. } \\
\text { - In the reading practice the students were asked to repeat after the teacher for } \\
\text { only some parts. } \\
\text { - The class still lacked the game part. }\end{array}$ \\
\hline
\end{tabular}

As table 12 and 13 reveal the only classes that received negative feedbacks were the first two classes and the second class was uninfluenced by the supervision program. In the first class the teacher did his best to follow the guidelines he was provided with and it was evident in the next session of observation. In the second class the teacher who was from the second teaching experience group (6 to 10 years) did not pay any attention to the supervisor's feedback and 
continued to attach to his own method of teaching. A look at the questionnaire responses of this group also reveals that these teachers tend to develop more negative attitudes towards teaching supervision. These attitudes are analyzed and explained in details in the next part.

\section{Teachers' Attitude and Their Teaching Experience}

To examine the influence of teachers' experience on their attitudes towards classroom supervision a non-parametric Kruskal-Wallis test was run. The reason for using a non-parametric test was that the distribution of the data population was not normal. Table 14 demonstrates the descriptive results and table 15 shows the results of non-parametric test.

TABLE 14.

NUMBERS AND AVERAGE RANKS OF TEACHERS WITH DIFFERENT TEACHING EXPERIENCES

\begin{tabular}{|l|l|l|}
\hline Years of Experience & N & Mean Rank \\
\hline $1-5$ & 20 & 2.5 \\
$6-10$ & 27 & 1.2 \\
$11-15$ & 7 & 2 \\
$16-20$ & 14 & 2 \\
+20 & 6 & 2 \\
Total & 74 & \\
\hline
\end{tabular}

TABLE 15.

RESULTS OF KRUSKAL-WALLIS TEST WITH FIVE INDEPENDENT GROUPS OF 1-5, 6-10, 11-15, 16-20, AND +20 TEACHING EXPERIENCE

\begin{tabular}{|l|l|}
\hline & Teachers' attitude \\
\hline Chi-Square & 22.443 \\
df & 4 \\
Asymp. Sig. & .000 \\
\hline
\end{tabular}

As Table 15 reveals, there is a statistically significant difference in teachers' attitude towards classroom supervision depending on the number of years of teaching experience, $\chi^{2}(4)=22.443, P=0.000$.

Since there is not a post hoc option for non-parametric test in SPSS, I compared the groups two by two running Mann Whitney tests to see which pairs of groups differ significantly. Table 16 shows the results of these comparisons.

TABLE 16.

RESULTS OF MANN-WHITNEY TEST WITH TWO INDEPENDENT GROUPS OF BA AND MA

\begin{tabular}{|c|c|c|c|}
\hline Groups & Mann-Whitney U & $\mathrm{Z}$ & Asymp. Sig. (2-tailed) \\
\hline $\begin{array}{l}1-5 \\
6-10\end{array}$ & $100.500^{*}$ & -3.876 & .000 \\
\hline $\begin{array}{l}1-5 \\
11-15\end{array}$ & $35.000 *$ & -2.219 & .027 \\
\hline $\begin{array}{l}1-5 \\
16-20\end{array}$ & $89.000^{*}$ & -2.073 & .038 \\
\hline $\begin{array}{l}1-5 \\
+20 \\
\end{array}$ & 39.500 & -1.415 & .157 \\
\hline $\begin{array}{l}6-10 \\
11-15 \\
\end{array}$ & $56.000 *$ & -1.827 & .048 \\
\hline $\begin{array}{l}6-10 \\
16-20\end{array}$ & $99.000 *$ & -2.759 & .006 \\
\hline $\begin{array}{r}6-10 \\
+20 \\
\end{array}$ & $41.500 *$ & -2.025 & .043 \\
\hline $\begin{array}{l}11-15 \\
16-20 \\
\end{array}$ & 42.000 & -1.026 & .305 \\
\hline $\begin{array}{l}11-15 \\
+20\end{array}$ & 17.500 & -1.080 & .280 \\
\hline $\begin{array}{l}16-20 \\
+20\end{array}$ & 41.000 & -.133 & .894 \\
\hline
\end{tabular}

* The difference is significant.

According to the table, at a critical level for rejection of 0.05 , teachers with 1-5 years of experience differ significantly with teachers with 6-10, 11-15, and 16-20 years of experience $(U=100.500, Z=-3.876, p=0.000$; $U=$ $35.000, \mathrm{Z}=-2.219, \mathrm{p}=0.027$; and $\mathrm{U}=89.000, \mathrm{Z}=-2.073, \mathrm{p}=0.038$ ).

In addition, the attitudes of teachers who have been teaching English for 6 to 10 years towards supervision are significantly different with the attitudes of those who have more than 11 years of teaching experience $(\mathrm{U}=56.000, \mathrm{Z}=-$ 1.827, $\mathrm{p}=0.048 ; \mathrm{U}=99.000, \mathrm{Z}=-2.759, \mathrm{p}=0.006 ;$ and $\mathrm{U}=41.500, \mathrm{Z}=-2.025, \mathrm{p}=0.043$ ). 
All in all, the results reveal that the attitude of less experienced teachers towards their class supervision seems to be different from more experienced ones. A look at table 14 and the mean ranks shows that teachers who have been teaching English for less than five years appear to hold more positive attitudes (mean rank $=2.5$ ) . Another interesting point in table 14 is that those teacher with six to ten years of teaching experience were the most pessimist amongst others (mean rank $=1.2$ ).

\section{SUMMARY OF FINDINGS}

This study was an attempt to discover Iranian EFL teachers' attitude towards supervision and its influence on classroom decision making and an account of their differences and similarities in this respect. The study also explored the relationship between teachers' teaching experience and their attitude towards classroom supervision. Below, I bring the summary of findings in separate sections according to the research questions.

\section{A. Teachers' Attitudes towards Classroom Supervision}

The first thing to be noticed is that Iranian teachers' attitudes and perceptions towards classroom observation are mostly characterized by an unconcerned feeling as the percentage of undecided responses in almost all questions and parts were relatively high.

When asked to evaluate classroom supervision generally, the majority of the participants considered it useful, half the participants found the supervision program necessary however only one teacher in four considered classroom supervision beyond inevitable organizational and administrative paperwork duties.

From the results of the participants' evaluation of the mode of supervision it is evident that from Iranian EFL teachers' perspective the current supervision is more of an authoritative practice mostly characterized by inspection and evaluation. The majority of participants feel that supervision focuses mostly on them therefore feel the fear of being penalized by bureaucratic administrators. This shows that the current supervision seems to be a stressful experience for the teachers.

The findings of the study regarding the teachers' perceptions towards the contribution of supervision to their growth shows that from Iranian EFL teachers' point of view the current supervision that they receive helps them better understand their shortcomings and solve problems in the classroom and lead to the growth of their teaching skills and improvement of instruction. However, fewer participants believed that supervision has a positive impact on their professional and career development in the long-term. In addition, classroom supervision does not seem to help teachers in their courses by providing educational materials.

The results of the analysis of teachers reaction to their supervision program shows that the majority of teachers showed a positive behavior towards supervision. Most teachers said they read the report carefully and use it to improve their teaching practice. However, the number of teachers who were unwilling to change their teaching approach based on the notes of the supervisor in the supervision report are considerable.

\section{B. Supervision and Teachers' Decision Making}

The results of the qualitative analysis revealed that supervision as an educational practice with the aim of teaching and learning improvement is only meaningful for those teachers having less than 10 years of teaching experienced. For the more experienced teachers it seems to be matter of official procedure and formality.

The results of the second session of observation showed that only those teachers who have been teaching for less than five years were attentive to the supervisors' feedbacks and their classroom decision making was influenced by the comments the supervisors provided. In the second class whose teacher had eight years of teaching experience, however, the teacher seemed reluctant to change his method of teaching and his instructional decisions according to the feedback he was provided with. In other words, teachers of the second teaching experience group (6 to 10 years) seemed uninfluenced by the supervision program.

\section{Teachers' Attitude and Their Teaching Experience}

The results of the quantitative analysis revealed that the attitude of teachers who have been teaching English for less than five years towards their class supervision was significantly different from others. These teachers hold more positive attitudes towards supervision.

Teachers with six to ten years of teaching experience also react to supervision significantly different from other teachers. These teachers appeared to be the most pessimist amongst others.

\section{DISCUSSION}

As mentioned in the earlier parts, the study revealed that the Iranian EFL teachers seemed indifferent towards classroom supervision in general when compared with teachers in other countries and contexts (Kutsyuruba, 2003; Kayaoglu, 2012; Acheson \& Gall, 1997). Further qualitative and quantitative analyses showed that the high number of undecided items in the questionnaire can be attributed to the fact that supervision is a matter of official rules and regulations rather than a process for educational improvement for teachers who have been teaching English for ten years 
and more. In fact, it can be argued that in the Iranian context supervision as it is defined and with objectives it is meant to achieve is only meaningful for less experienced teachers.

Among the less experienced teachers those who had less than five years of teaching experience were found to be more influenced by the supervision process when it came to making decisions in the classroom. These teachers indicated the importance of supervision for their classroom improvement and their teaching skills and appeared to hold positive attitudes towards supervision program they were experiencing. This is contrary to the cases of Kayaoglu (2012) in Turkey and Acheson and Gall (1997) in Zimbabwe.

It is also contrary to the attitudes of those Iranian teachers who had teaching experience of between 5 to 10 years. These participants appeared to hold negative attitudes towards supervision. In the qualitative part of the study though the supervisor mentioned negative remarks in the observation form, the case study teacher refused to take them into account. This pessimistic view about supervision and the denial seems to be due to the fact that these teachers have enough experience to claim originality and refuse the supervision program that is biased towards evaluation or inspection. Keep in mind that the Iranian EFL teachers who participated in this study thought that the supervision program is authoritative rather than democratic in general. This calls for a change in the mode of supervision according to the characteristics of teachers and an invitation of a more equal and collaborative manner of supervision as according to Cogan (1973) one of the main factors that affect supervision efficiency is the relation of teachers to supervisors. This relationship is expected to be collegial rather than authoritarian in order to attract the teachers' positive attitude.

\section{CONCLUSION}

Supervision of instruction includes monitoring and evaluating classroom teaching practice and collecting data according to a set of predefined standards appointed by the administrator with the aim of providing appropriate feedback and guidance to teachers to improve teaching in order to enhance student learning. However, as the results of the presents study shows this was not the case for all the teachers in the Iranian EFL context.

A conclusion than can be drawn from the available evidence is that the supervisory in Iran needs to take into account the capabilities and characteristics of every teacher. Not a similar model of supervision is suitable and efficient for all the teachers. In the case of this study while the particular method of supervision that was generally characterized as an error finding procedure with the aim of standardizing and control seemed to be efficient for the teachers who have had less than five years of experience it seemed ineffective for experienced teachers.

In fact the teachers who have had between 5 to 10 years of teaching experience found the program delimiting and a barrier to academic freedom. These teachers showed their disapproval by ignoring the feedback they received.

In addition, from the results of the qualitative analysis it can be concluded that the supervision program obviously failed to function for those teachers who had 16 years of teaching experience and more as well. In this case, the program seemed to be only a paperwork job. That is, instead of adapting the supervision program with these teachers and their characteristics, the administrators tried to keep up appearances.

\section{REFERENCES}

[1] Acheson, K. A., \& Gall, M. D. (1997). Techniques in the clinical supervision of teachers: Preservice and inservice applications (4th ed.). New York: Longman.

[2] Brehm, S.S. \& Kassin, S.M. (1990). Social Psychology. Boston: Houghton Mifflin.

[3] Burnham, R.B. (1976). Instructional supervision: past, present and future perspectives. Theory into Practice. 15(4), 301-305.

[4] Cogan, M. L. (1973). Clinical supervision. Boston: Houghton-Mifflin.

[5] Edson, A. W. (1893). School Supervision. Education, 3, 391-96.

[6] Feldman, R. S. (1995). Social Psychology. New Jersey: Prentice-Hall

[7] Franzoi, S. L. (2003). Social Psychology. New York: McGraw-Hill.

[8] Fraser, K. (1980). Supervisory behaviour and teacher satisfaction. Journal of Education Administration, 18(2), $224-227$.

[9] Garmston, R.J. (1987). How administrators support peer coaching. Educational Leadership, 44 (5), 128-26.

[10] Glanz, J. (1977). Ahistoricism and School Supervision: Notes towards a History. Educational Leadership, 35(2), $148-154$.

[11] Glanz, J. (2006). What every principal should know about instructional leadership. Thousand Oaks, CA: Corwin Press.

[12] Glickman, C. D. (1990). Supervision of instruction: A development approach. Boston, MA: Allyn and Bacon.

[13] Glickman, C. D., Gordon, S. P., \& Ross-Gordon, J. M. (1998). Supervision of Instruction: A development approach (4th ed.) Needham, MA: Allyn and Bacon.

[14] Glickman, C. D., Gordon, S. P., \& Ross-Gordon, J. M. (2001). Supervision and instructional leadership (5 ${ }^{\text {th }}$ ed.). Needham Heights, MA: Allyn \& Bacon.

[15] Goldhammer, R. (1969). Clinical Supervision. New York, NY: Holt, Rinehart and Winston.

[16] Goldhammer, R., Anderson, R. H., \& Krajewski R. J. (1980). Clinical supervision: Special methods for the supervision of teachers. New York: Holt, Rinehart, and Winston.

[17] Gordon, S. P. (1990). Developmental Supervision: An Exploratory Study of a Promising Model. Journal of Curriculum and Supervision, 5(4), 293-307.

[18] Gordon, S. P. (1997). Has the field of supervision evolved to a point that it should be called something else? As cited in J. Glanz \& Neville (Eds.), Educational supervision: Perspectives, issues, and controversies (114-123). Norwood, MA: Christopher-Gordon.

[19] Harris, B.M. (1985). Supervision behaviours in education. (3rd ed.). New Jersey: Prentice Hall. 
[20] Kayaoglu, M. N. (2012). Dictating or Facilitating: The Supervisory Process for Language Teachers. Australian Journal of Teacher Education, 37(10), 103-117.

[21] Kimbrough, R. B., \& Burkett, C. W. (1990). The principalship: Concepts and practices. Englewood Cliffs, NJ: Prentice-Hall.

[22] Kindsvatter, R. Willen, W. \& Ishler, M. (1988). Dynamics of Effective Teaching. New York: Longman.

[23] Kutsyuruba, V. (2003). Instructional supervision: Perceptions of Canadian and Ukrainian beginning high-school teachers. Unpublished master's thesis, University of Saskatchewan, Saskatoon, Saskatchewan, Canada.

[24] Lucio, W. H. \& McNeil, J. D. (1962). A synthesis of thought and action. New York, NY: McGraw-Hill.

[25] McFaul, S. \& Cooper, J. (1984). Peer Clinical Supervision: Myth or Reality? Educational Leadership, 41(6), 4-9.

[26] Moon, J. (2000). Children Learning English. Oxford Macmillan: Heinemann.

[27] Munro, P. \& Elliott, J. (1987). Instructional Growth through Peer Coaching. Journal of Staff Development, 8(1), $25-28$.

[28] Neagley, R.L. \& Evans, D.N. (1964). Handbook for effective supervision of instruction. New Jersey: Prentice Hall.

[29] Okafor, P. Leadership in Instructional Supervision. Retrieved from http://patrickokafor.com/files/ClinicalSupervision.pdf on 12 November 2012.

[30] Pavan, B. N. (1983,). Clinical supervision: Does it make a difference? Paper presented at the annual meeting of the Council of Professors of Instructional Supervision. DeKalb, IL.

[31] Richards, J. C. \& Lockhart, C. (1996). Reflective Teaching in Second Language Classrooms. Cambridge: Cambridge University Press.

[32] Richards, J. C. (1998). Beyond Training. Cambridge: Cambridge University Press.

[33] Robbins, P. (1991). How to Plan and Implement a Peer Coaching Program. Alexandria, VA: Association for Supervision and Curriculum Development.

[34] Sergiovanni, T. \& Starrat, R. J. (1983). Supervision for human perspective. New York: McGraw Hill.

[35] Showers, B. (1984). Peer coaching: A strategy for facilitating transfer of training. Eugene, OR: Center for Educational Policy and Management.

[36] Smith, B. D. (1996). Teacher decision-making in the adult ESL classroom. In D. Freeman \& J. C. Richards (Eds.), Teacher learning in language teaching (197- 216). Cambridge: Cambridge University Press.

[37] Snyder, K. (1981). Clinical supervision in the 1980's. Educational Leadership, 38(7), 521-524.

[38] Stimpson, P., Lopez-Real, F., Bunton, D., Chan Wal-Keung, D., Sivan, A. \& Williams, M. (2000). Better Supervision, Better Teaching: A Handbook for Teaching Practice Supervisors. Hong Kong: Hong Kong University Press.

[39] Sullivan, S. \& Glanz, J. (2000). Supervision that improves teaching: Strategies and techniques. Thousand Oaks, CA: Corwin Press, Inc.

[40] Trappes-Lomax H. \& I. McGrath (eds) (1999). Theory in language teacher education. Longman in association with the British Council.

[41] Ulichny, P. (1996). What's in a methodology? In D. Freeman \& J. C. Richards (eds.), Teacher Learning in Language Teaching. Cambridge: Cambridge University Press. 178-196.

[42] White, B. L. \& Daniel, L. G. (1996). Paper presented at the annual meeting of the mid-south educational resource center. (Report No. ED 403 641). Tuscaloosa, AL. Nov. 6-8.

[43] Wiles, K. \& Lovell, J. (1975). Supervision for better schools. USA: Prentice Hall.

[44] Zepeda, S. J. (2007). Instructional Supervision Applying Tools and Concepts. Larchmont, NY: Eye on Education.

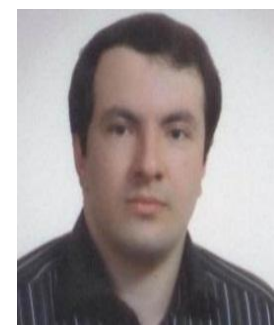

Ramin Rahmany is a Ph.D. holder of teaching English as a foreign language from Tehran University, Iran. Currently, he is an assistant professor in Azad University of Takestan, Iran.

His major interests are language and acquisition, computer assisted language learning, and psycholinguistics. He has taught several courses at university like Language methodology and discourse analysis.

He has published several articles in language learning acquisitions e.g. Acquisition of English Relative Clauses by Persian EFL Learners published by Journal of Language and Linguistic Studies in October 2009.

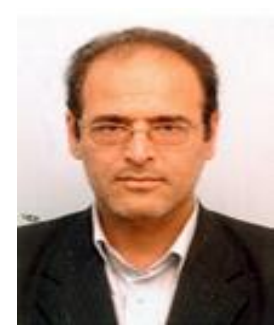

Mohammad Taghi Hassani assistant professor in TEFL at Imam Hossein University, Tehran and Islamic Azad University, Takestan Branch, Iran. His research interests are EFL writing, psycholinguistics, phonetics, contrastive analysis, English for Specific Purposes, and language teaching methodology.

He has published several articles in language teaching and learning e.g. The effect of Self Assessment on Iranian EFL learners' writing skill, published by Iranian EFL Journal in October 2012. 


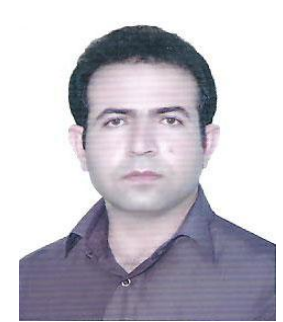

Kaivan Parhoodeh was born in Kermanshah, Iran in 1979. He received an MA in TEFL from Azad University Takestan Branch, Iran. He, with five years of teaching experience, in Shaheed Satari University \& Air Force Language Commander Center. At present he is teaching English in Azad University Gillan-e- Gharb center, Iran. His favorite field of research and study is testing and teacher education. 